\title{
Analisis Faktor Kejadian Depresi Pada Klien Pasca Stroke
}

\section{Suku Banjar Banjarmasin}

\author{
Mohammad Basit1, Rifa'atul Mahmudahı \\ 1Universitas Sari Mulia Banjarmasin \\ *Correspondence Author: Telepon: +6287814600203, E-mail:syafabasit@gmail.com, \\ rivaayoenani@gmail.com
}

DOI: https://doi.org/10.33859/dksm.v10i2.508

\begin{abstract}
Abstrak
Latar Belakang: Masalah gejala depresi pasca stroke sering tidak terdeteksi oleh dokter nonspikiater, padahal penangan yang lebih awal, tepat, dan terpadu akan lebih efektif dengan demikian dapat membantu meningkatkan proses penyembuhan. Aktivitas sehari-hari penderita stroke dibantu oleh keluarga atau perawat, ingin menyampaikan maksud dan tujuan juga tidak mampu, hanya bisa menggunakan bahasa tubuh atau isyarat untuk menyampaikan apa yang diinginkan. Ada beberapa stresor psiko-sosial yang kemungkinan menyebabkan depresi pada penderita penyakit stroke yaitu jenis kelamin, umur, ras, pendapatan, pendidikan, pekerjaan, status perkawinan, dan geografi. Di Kalimantan Selatan tercatat sebagai daerah dengan penderita hipertensi dan stroke tertinggi Nasional, disebabkan suku banjar mempunyai kebiasaan pola makan dan pola hidup menyukai makanan manis, berlemak, serta asin yang tidak diimbangi dengan sayur mayur serta olahraga yang cukup

Tujuan: Untuk menganalisis faktor kejadian depresi pada klien pasca stroke suku Banjar Banjarmasin

Metode: Menggunakan observasional analitik, dengan rancangan atau desain studi kasus kontrol (case control study). Populasi pada penelitian ini adalah seluruh suku Banjar yang mengalami stroke, dengan teknik sample purposive sampling dengan 66 orang. Data dianalisis dengan Spearman-Rank test with $\alpha=0.05$

Hasil: Ada hubungan antara jarak geografis dengan kejadian depresi pada klien pasca stroke dengan nilai $\mathrm{p}=0,015$ dan ada hubungan dukungan sosial dengan kejadian depresi pada klien pasca stroke suku Banjar Banjarmasin dengan nilai 0,000

Kesimpulan: ada dua faktor yang berhubungan dengan kejadian depresi pada klien pasca stroke suku Banjar Banjarmasin di Poliklinik Syaraf RSUD Ulin Banjarmasin, yaitu jarak geografis dan dukungan sosial
\end{abstract}

Kata Kunci: Faktor Depresi, Stroke, Suku Banjar 


\section{Abstract}

Background: Phenomenon of post-stroke depression are often not detected by non-psychiatrist doctor, whereas earlier handlers, right, and integrated will be more effective so that it can help improve the healing process. There are some psychosocial stressors which is likely to cause of stroke patients in Kalimantan Selatan, because the Banjarese has a bad habits and lifestlye like always ate salty food, fatty, etc that are not balanced with enough vegetables and exercise.

Objective: To analyzed the factor of post-stroke depression on Banjarese Clients in Banjarmasin Method: This study used observational method with case control design. The population are Banjarese Clients post-stroke in Banjarmasin, sampling techniques in this research was purposive sampling method with 66 people. Data were analyzed with Spearman-Rank test with $\alpha=0.05$.

Results: There are no correlation between age, gender, education level, marital status, job, family income, stroke severity, long suffered stroke, types of stroke, and personality with post-stroke depression on Banjarese Clients in Banjarmasin.

There are correlation between geographical distance with post-stroke depression with value $p=$ 0,015 and there was correlated significantly relationship by social support with post-stroke depression by the value $p=0,000$

Conclusion: There was two factors related with post stroke depression on Bajarese Clients in Poliklinik Syaraf Ulin Hospital Banjarmasin, namely geographical distance and there is significantly relationship by social support.

Keywords: Banjarese, Depression Factors, Stroke

\section{Pendahuluan}

Gejala depresi pasca stroke sering tidak terdeteksi oleh tenaga kesehatan non-spikiater, penangan yang lebih awal, tepat, dan terpadu akan lebih efektif akan membantu meningkatkan proses penyembuhan. Aktivitas sehari-hari pederita stroke dibantu oleh keluarga atau perawat, ingin menyampaikan maksud dan tujuan juga tidak mampu, hanya bisa menggunakan bahasa tubuh atau isyarat untuk menyampaikan apa yang diinginkan. Hal tersebut membuat klien stroke mengalami depresi, apalagi jika klien memiliki keluarga yang support sistemnya kurang. Ada beberapa stresor psikososial yang kemungkinan menyebabkan depresi pada penderita penyakit stroke adalah jenis kelamin, umur, ras, pendapatan, pendidikan, pekerjaan, status perkawinan, dan geografi. Data dari Dinas Kesehatan Kalimantan Selatan pada tahun 2016 bahwa Kalimantan Selatan tercatat sebagai daerah dengan hipertensi dan stroke tertinggi Nasional. Disebabkan suku banjar mempunyai kebiasaan pola makan dan pola hidup menyukai makanan manis, berlemak, serta asin yang tidak 
diimbangi dengan sayur mayur serta olahraga

yang cukup.

\section{Metode}

Jenis penelitian adalah observasional analitik, dengan rancangan atau desain studi kasus kontrol (case control study). Populasi pada penelitian adalah Pasien Pasca Stroke Suku Banjar dengan memperhatikan tingkat depresi di poliklinik syaraf RSUD Ulin Banjarmasin. Sedangkan teknik pengambilan sampel pada penelitian adalah purposive sampling dengan menggunakan kuesioner untuk faktor faktor yang mempengaruhi dan kuesioner Carroll Rating Scale for Depression (CRS) untuk tingkat depresi. Analisis data yang digunakan adalah univariat dan bivariat. dianalisa menggunakan komputer program.

\section{Hasil}

1. Hasil analisis menggunakan SpearmanRank test dengan nilai p $0.092>\alpha 0.05$. Ho di terima. Artinya tidak ada hubungan antara usia dengan terjadinya depresi di poliklinik syaraf RSUD Ulin Banjarmasin

2. Hasil analisis menggunakan SpearmanRank test dengan nilai p $0.424>\alpha 0.05$. Ho di terima. Artinya tidak ada hubungan antara jenis kelamin dengan terjadinya depresi di poliklinik syaraf RSUD Ulin Banjarmasin

3. Hasil analisis menggunakan SpearmanRank test dengan nilai $\mathrm{p} 0.363>\alpha 0.05$. Ho di terima. Artinya tidak ada hubungan antara tingkat pendidikan dengan terjadinya depresi di poliklinik syaraf RSUD Ulin Banjarmasin

4. Hasil analisis menggunakan SpearmanRank test dengan nilai p $0.695>\alpha 0.05$. Ho di terima. Artinya tidak ada hubungan antara status perkawinan dengan terjadinya depresi di poliklinik syaraf RSUD Ulin Banjarmasin

5. Hasil analisis menggunakan SpearmanRank test dengan nilai p p 0.202> $\alpha 0.05$. Ho di terima. Artinya tidak ada hubungan antara pekerjaan dengan terjadinya depresi di poliklinik syaraf RSUD Ulin Banjarmasin

6. Hasil analisis menggunakan SpearmanRank test dengan nilai p $0.448>\alpha 0.05$. Ho di terima. Artinya tidak ada hubungan 
antara factor penghasilan keluarga dengan terjadinya depresi.

7. Hasil analisis menggunakan SpearmanRank test dengan nilai $\mathrm{p} 0.015>\alpha 0.05$. Ho di tolak. Artinya ada hubungan antara jarak geografis dengan terjadinya depresi

8. Hasil analisis menggunakan SpearmanRank test dengan nilai $\mathrm{p} 0.433>\alpha 0.05$. Ho diterima. Artinya tidak ada hubungan antara keparahan stroke dengan terjadinya depresi.

9. Hasil analisis menggunakan SpearmanRank test dengan nilai p $0.475>\alpha 0.05$. Ho diterima. Artinya tidak ada hubungan antara lama menderita stroke dengan terjadinya depresi.

10. Hasil analisis menggunakan SpearmanRank test dengan nilai p 0.448 dengan semua pasien SNH. Pasien yang mendertia depresinya normal sebanyak 16 orang (24.2\%). Depresi ringan sebanyak 30 orang (45.5\%) dan depresi sedang berjumlah 20 orang $(30.3 \%)$

11. Hasil analisis menggunakan SpearmanRank test dengan nilai $\mathrm{p}(0.000)>\alpha(0.05)$.
Ho ditolak. Artinya ada hubungan antara dukungan sosial dengan terjadinya depresi.

12. Hasil analisis menggunakan SpearmanRank test dengan nilai $\mathrm{p} 0.827>\alpha 0.05$. Ho di terima. Artinya tidak ada hubungan antara tipe kepribadian dengan terjadinya depresi.

\section{Pembahasan}

1. Analisis faktor usia dengan terjadinya depresi di poliklinik syaraf RSUD Ulin Banjarmasin

Dari 66 orang responden penderita stroke usia terbanyak yaitu pada usia 51-70 tahun sebanyak 45 responden $(68,2 \%)$ Hasil analisis dengan menggunakan uji statistik Spearmen-Rank menunjukkan $\mathrm{p}$ value sebesar 0,092 , nilai tersebut secara statistik bermakna $p(0,092)$ $>\alpha(0,05)$ maka Ho diterima. Artinya tidak terdapat hubungan antara usia dengan terjadinya depresi pasca stroke di Poliklinik Syaraf RSUD Ulin Banjarmasin.

Sebagian besar responden berusia 51-70 tahun yang mengalami depresi ringan sebanyak 21 orang $(31.8 \%)$ klien dengan usia 35-50 tahun hanya ada 9 
orang yang mengalami depresi ringan $(13,6 \%)$. Klien yang berusia 51-70 tahun mengalami depresi sedang ada 11 orang $(16,7 \%)$ dan klien yang berusia $35-50$ tahun mengalami depresi sedang ada 9 orang $(13,6 \%)$.

Hal ini sejalan dengan penelitian yang dilakukan (Carole, 2011) dalam Darussalaman pada (2011), menggambarkan makin tua usia penderita stroke kecenderungan mengalami depresi semakin besar. Depresi sebagai dampak dari gangguan fungsional, dan tidak adanya dukungan sosial. Penderita yang berusia muda mempunyai depresi yang lebih berat. Depresi merupakan masalah yang lazim dijumpai pada penderita pasca stroke. Menghadapi kemunduran mobilitas, kekuatan fisik, kesulitan kerja, kemampuan kognitif akan mencetuskan munculnya depresi. Apalagi hal ini jika dialarni oleh penderita usia muda akan dapat membuat ineteka depresi.. Ini juga didukung oleh pendapat Syaiiendra, sekitar $50 \%$ pasien depresi terjadi pada usia 20-50 tahun diniana prevatensinya (angka kejadian) pada orang yang tidak menikah lebih tinggi dibanding mereka yang berumah tangga.

\section{Analisis Faktor Jenis Kelamin dengan} terjadinya depresi di poliklinik syaraf RSUD Ulin Banjarmasin

Dari 66 orang responden penderita stroke usia terbanyak yaitu pada laki-laki sebanyak 47 responden $(71,2 \%)$. Pada hasil penelitian bahwa Klien pasca stroke di Poliklinik Syaraf RSUD Ulin Banjarmasin sebagian besar berjenis kelamin laki-laki yang mengalami depresi ringan sebanyak 20 orang $(30.3 \%)$ klien perempuan hanya ada 10 orang yang mengalami depresi ringan $(15,2 \%)$. Klien yang berjenis kelamin laki-laki mengalami depresi sedang ada 16 orang $(24,2 \%)$ dan klien yang berjenis kelamin perempuan mengalami depresi sedang ada 4 orang $(6,1 \%)$

Sebagian besar berjenis kelamin laki-laki yang mengalami depresi ringan sebanyak 20 orang $(30.3 \%)$ klien perempuan hanya ada 10 orang yang mengalami depresi ringan $(15,2 \%)$. Klien 
yang berjenis kelamin laki-laki mengalami depresi sedang ada 16 orang $(24,2 \%)$ dan klien yang berjenis kelamin perempuan mengalami depresi sedang ada 4 orang $(6,1 \%)$

Penelitian yang dilakukan oleh Azra Alajbegovic et al tahun 2014 mengatakan bahwa dibandingkan dengan laki-laki sebesar (27,2\%), kejadian depresi pasca stroke lebih tinggi pada perempuan yaitu sebesar $(63,8 \%)$. Hal ini konsisten dengan temuan Paolucci dan Cassidy, hal ini mungkin karena pasien wanita lebih rentan terhadap faktor stress psikologis dan sosial, dan kemudian mengakibatkan gangguan keseimbangan psikologis fisik.

\section{Analisis Faktor Tingkat Pendidikan} dengan terjadinya depresi di poliklinik syaraf RSUD Ulin Banjarmasin

Tingkat pendidikan SD yang mengalami depresi ringan sebanyak 5 orang $(7,6 \%)$ klien dengan SLTP ada 10 orang yang mengalami depresi ringan $(13,6 \%)$ klien dengan SLTA yang mengalami depresi ringan ada 9 orang $(13,6)$ dan klien dengan S1 yang mengalami depresi ringan ada 6 orang $(9,1 \%)$. Klien yang berpendidikan SD yang mengalami depresi sedang ada 3 orang $(4,5 \%)$ klien yang SLTP mengalami depresi sedang ada 4 orang $(6,1 \%)$ klien dengan SLTA mengalami depresi sedang ada 6 orang $(9,1 \%)$ dan klien dengan S1 yang mengalami depresi sedang ada 7 orang $(10,6 \%)$.

Hal ini sejalan dengan penelitian Dian Nastiti (2012) bahwa berdasarkan tingkat pendidikan dari 152 pasien stroke rawat inap di RSKM tahun 2011, didapatkan proporsi terbanyak adalah tamat SMA, yaitu 123 paien (81\%). Sedangkan sebanyak 14 pasien (9\%) memiliki tingkat pendidikan terakhir tamat SMP sebanyak 9 pasien (6\%) dan tamat SD 6 pasien $(4 \%)$

Tingkat pendidikan sebagai faktor sosial ekonomi memang tidak berkaitan langsung dengan kejadian stroke. Akan tetapi, tingkat pendidikan seseorang menentukan sikap orang tersebut terhadap prilaku sehat (Notoatmojo, 2015) dalam dian Nastiti (2012). Stroke merupakan 
penyakit tidak menular yang terjadi akibat factor lingkungan dan degenerative, dimana gaya hidup serta prilaku makan seseorang perlu diperhatikan. Dalam Framingham Study di Massachusetts menunjukkan bahwa rata-rata tekanan darah pada kelompok dengan orang tingkat pendidikan yang lebih rendah dibandingkan dengan kelompok orang yang berpendidikan rendah, Dian Nastiti (2012). Oleh karena itu, seseorang dengan tingkat pendidikan yang lebih tinggi diharapkan mampu memahami informasi kesehatan dan mengaplikasikannya dalam kehidupan sehari-hari.

Dalam penelitian ini pasien dengan tingkat pendidikan SLTP dan SLTA mengalami strok tertinggi dari pada tingkat pendidikan sarjana. Hal ini mungkin disebabkan oleh status ekonomi yang berpendidikan rendah tidak mampu menjangkau pelayanan kesehatan, dan terdeteksi menderita penyakit stroke ini.

Hasil analisis dengan menggunakan uji statistik Spearmen-Rank menunjukkan $\mathrm{p}$ value sebesar 0,363 , nilai tersebut secara statistik bermakna $p(0,363)>\alpha(0,05)$

maka Ho diterima. Artinya tidak terdapat hubungan antara tingkat pendidikan dengan terjadinya depresi pasca stroke di Poliklinik Syaraf RSUD Ulin Banjarmasin.

\section{Analisis Faktor Status Perkawinan} dengan terjadinya depresi di poliklinik syaraf RSUD Ulin Banjarmasin

Sebagian besar dengan status kawin yang mengalami depresi ringan sebanyak 25 orang $(37,9 \%)$ klien yang belum kawin tidak ada yang mengalami depresi ringan, klien yang cerai mati mengalami depresi ringan ada 5 orang $(7,6 \%)$. Klien dengan status kawin yang mengalami depresi sedang ada 16 orang $(24,2 \%)$ klien yang belum kawin mengalami depresi sedang ada 2 orang (3\%) klien yang cerai mati mengalami depresi sedang ada 2 orang $(3 \%)$.

Hasil analisis dengan menggunakan uji statistik Spearmen-Rank menunjukkan $\mathrm{p}$ value sebesar 0,695 , nilai tersebut secara statistik bermakna $p(0,695)$ $>\alpha(0,05)$ maka Ho diterima. 
Hal ini tidak sejalan dengan

penelitian yang dilakukan oleh Dimas Adhi

Pradita dan Ida Rochmawati tahun 2013

menyatakan bahwa tidak terdapat

hubungan secara bermakna pada status

pernikahan. Data yang ada, depresi lebih

banyak terjadi pada responden yang sudah

menikah dibandingkan yang tidak menikah

(janda/duda). Bagi sebagian orang,

pernikahan dapat dinilai sebagai suatu

stresor dikarenakan orang yang menikah

memiliki tanggungan hidup yang lebih

besar dibandingkan yang tidak menikah.

\section{Analisis Faktor Pekerjaan dengan}

terjadinya depresi di poliklinik syaraf

\section{RSUD Ulin Banjarmasin}

Sebagian besar dengan pekerjaan swasta yang mengalami depresi ringan sebanyak 19 orang $(28,8 \%)$ klien dengan pekerjaan IRT yang mengalami depresi ringanada 8 orang $(12,1 \%)$ klien yang PNS mengalami depresi ringan ada 3 orang $(4,5 \%)$. Klien dengan pekerjaan swasta yang mengalami depresi sedang ada 15 orang $(22,7 \%)$ klien dengan pekerjaan IRT yang mengalami depresi sedang ada 1 orang $(1,5 \%)$ klien yang PNS mengalami depresi sedang ada 4 orang (6,1\%). Hasil analisis dengan menggunakan uji statistik Spearmen-Rank menunjukkan $\mathrm{p}$ value sebesar 0,202 , nilai tersebut secara statistik bermakna $p(0,202)>\alpha(0,05)$ maka Ho diterima.

Hal ini tidak sejalan dengan penelitian yang dilakukan oleh Dimas Adhi Pradita dan Ida Rochmawati tahun 2013 ibu rumah tangga dan petani menduduki jumlah terbanyak pada penelitian ini. Walaupun hasil analisis data menunjukkan hasil yang tidak berhubungan, hal berbeda dikatakan oleh Wong danAlmeida (2012) bahwa status pekerjaan berhubungan depresi, dimana responden yang masih bekerja memiliki resiko terhadap depresi karena waktu mereka lebih banyak dihabiskan untuk bekerja di luar rumah.

\section{Analisis Faktor Penghasilan Keluarga} dengan terjadinya depresi di poliklinik syaraf RSUD Ulin Banjarmasin

Sebagian besar yang berpenghasilan $<2$ juta-5 juta mengalami depresi ringan sebanyak 22 orang $(33,3 \%)$ 
klien dengan penghasilan $>5$ juta-8 juta yang mengalami depresi ringanada 4 orang $(6,1 \%)$ dan klien dengan penghasilan $>8$ juta mengalami depresi ringan ada 4 orang $(6,1 \%)$. Klien dengan penghasilan $<2$ juta5 juta yang mengalami depresi sedang ada 14 orang $(21,2 \%)$ klien dengan penghasilan $>5$ juta- 8 juta yang mengalami depresi sedang ada 6 orang $(9,1 \%)$ dan klien dengan penghasilan $>8$ juta tidak ada yangmengalami depresi sedang. Hasil analisis dengan menggunakan uji statistik Spearmen-Rank menunjukkan $\mathrm{p}$ value sebesar 0,448 , nilai tersebut secara statistik bermakna $p(0,448)>\alpha(0,05)$ maka Ho diterima.

Hal ini sesuai dengan penelitian oleh Eun-Young Park, Jung-Hee Kim (2017). Pasien dengan stroke adalah pengguna layanan kesehatan jangka panjang dan biasanya memiliki biaya perawatan kesehatan yang tinggi . Penghasilan rendah telah ditemukan terkait dengan partisipasi yang kurang pada stroke. Selain itu, sekitar $20 \%$ penderita stroke tidak bekerja pasca stroke dan sekitar setengahnya harus mengganti pekerjaan. Dengan demikian, dalam kondisi kekurangan material, tingkat pendidikan yang lebih tinggi tidak menjamin penghasilan yang lebih tinggi. Karena ada hubungan yang kuat antara pendapatan rendah dan depresi di antara pasien.

\section{Analisis Faktor Geoggrafis dengan} terjadinya depresi di poliklinik syaraf RSUD Ulin Banjarmasin

Sebagian besar jarak rumah responden dengan pelayanan kesehatan 100M-2KM. Yang mengalami depresi ringan sebanyak 19 orang $(28,8 \%)$ klien dengan jarak 3KM-5KM yang mengalami depresi ringanada 8 orang $(12,1 \%)$ dan klien dengan jarak 6KM-8KM mengalami depresi ringan ada 3 orang (4,5\%). Klien dengan jarak 100M-2KM yang mengalami depresi sedang ada 15 orang $(22,7 \%)$ klien dengan 3KM-5KM yang mengalami depresi sedang ada 5 orang $(7,6 \%)$ dan klien dengan jarak 6KM-8KM tidak ada yang mengalami depresi sedang. 
Hasil analisis dengan

menggunakan uji statistik Spearmen-Rank

menunjukkan $\mathrm{p}$ value sebesar 0,015 , nilai

tersebut secara statistik bermakna $p(0,015)$

$<\alpha(0,05)$ maka Ho ditolak.

Hal ini tidak sejalan dengan teori

dari Tan, TY bahwa terdapat beberapa faktor yang dapat mempengaruhi perilaku kesehatan seseorang, antara lain geografis dan demografi. Faktor geografi seperti jarak antara rumah penderita dengan petugas kesehatan terdekat dapat mempengaruhi perilaku mencari pertolongan kesehatan. Selain itu, faktor jenis kelamin dan pendidikan rendah juga berpengaruh terhadapketerlambatan mencari pertolongan, Tan,TY (2012).

Pada penelitian ini, terdapat 3 alur yang menunjukkan perilaku pasien stroke dalam mencari pertolongan kesehatan. Alur pertama adalah pasien stroke langsung dibawa ke rumah sakit tanpa dibawa kemanapun sebelumnya. Semua pasien stroke yang langsung dibawa ke rumah sakit ini adalah stroke tipe perdarahan, oleh karena gejala yang muncul pada tipe perdarahan lebih berat dibanding tipe infark. Gejala yang paling sering muncul adalah pasien tidak sadarkan diri. Keadaan tidak sadarkan diri ini sering membuat panik keluarga sehingga pasien stroke dibawa ke rumah sakit sesegera mungkin. Perilaku keluarga untuk membawa pasien stroke langsung ke rumah sakit $\leq 3$ jam, disebut sebagai perilaku baik atau sesuai. Keluarga yang tidak segera membawa pasien stroke ke rumah sakit $\leq 3$ jam disebut dengan berperilaku buruk, Tan, TY (2012).

7. Analisis Faktor Keparahan Stroke dengan terjadinya depresi di poliklinik syaraf RSUD Ulin

\section{Banjarmasin}

Menunjukkan bahwa Klien pasca stroke di Poliklinik Syaraf RSUD Ulin Banjarmasin sebagian besar dengan tingkah keparahan sedang yang mengalami depresi ringan sebanyak 16 orang $(24,2 \%)$ klien dengan keparahan ringan yang mengalami depresi ringan ada 8 orang $(12,1 \%)$. Klien dengan keparahan sedang yang mengalami depresi sedang ada 12 
orang $(18,2 \%)$ klien dengan keparahan

ringan yang mengalami depresi sedang ada

8 orang $(12,1 \%)$.

Hasil analisis dengan menggunakan uji statistik Spearmen-Rank menunjukkan $\mathrm{p}$ value sebesar 0,433 , nilai tersebut secara statistik bermakna $p(0,433)$ $>\alpha(0,05)$ maka Ho diterima. Artinya tidak ada hubungan antara keparahan stroke dengan terjadinya depresi di Poliklinik Syaraf RSUD Ulin Banjarmasin. Hal ini berbanding terbalik dengan penelitian yang dilakukan oleh Ilut et al (2017) bahwa skor NIHSS (skor penilaian keparahan stroke) yang lebih tinggi dikaitkan dengan depresi berat, jadi seorang pasien dengan skor NIHSS lebih dari 11 memiliki potensi 9,4 kali lipat lebih tinggi mengalami depresi berat dari pada pasien dengan skor NIHSS dibawah 11. Penilaian NIHSS dapat memprediksi prognosis jangka panjang dan kondisi kognitif serta perilaku pasien stroke.

Menurut penelitian Meng (2017) bahwa setelah dianalisa antara kedua kelompok menunjukkan bahwa tingkat depresi lebih serius saat skor NIHSS lebih tinggi, dan skor HAMD lebih tinggi. Itu artinya saat kondisi stroke semakin buruk atau parah maka risiko depresi semakin tinggi.

\section{Analisis Faktor Lama}

\section{Menderita Stroke dengan terjadinya}

depresi di poliklinik syaraf RSUD Ulin

\section{Banjarmasin}

Menunjukkan bahwa Klien pasca stroke di Poliklinik Syaraf RSUD Ulin Banjarmasin sebagian besar lama menderita stroke $<1$ tahun yang mengalami depresi ringan sebanyak 26 orang $(39,4 \%)$ klien yang lama menderita $>1$ tahun mengalami depresi ringanada 4 orang $(6,1 \%)$. Klien yang lama menderita $<1$ tahun menderita mengalami depresi sedang ada 17 orang $(25,8 \%)$ dan klien yang lama menderita $>1$ tahun mengalami depresi sedang ada 3 orang $(4,5 \%)$.

$$
\text { Hasil analisis dengan }
$$
menggunakan uji statistik Spearmen-Rank menunjukkan $\mathrm{p}$ value sebesar 0,475 , nilai tersebut secara statistik bermakna $p(0,092)$ $>\alpha(0,05)$ maka Ho diterima. 
Hal ini tidak sependapat dengan

pendapat Wibisono, $\mathrm{S}$ yang menyatakan bahwa insiden depresi pasca stroke berkisar 11-68\% dengan prevalensi pada Ease akur: $25 \%, 3-12$ bulan. $32 \%,>1$ tahun. $16 \%$, setelah 2 tahun: 1 Wo dan $>3$ tahun: 29\%. Dan jika dilihat dari hasil penelitian, hal ini sesuai dengan pendapat di atas, bahwa prevalensi yang tertinggi kejadian depresi pada penderita pasca stroke.

Mayoritas penderita stroke $(40 \%)$ nya akan berkembang depresi dalam 1-2 bulan setelah stroke. Sebagian lainnya 10$20 \%$ nya akan berkembang depresi pada waktu setelah 1-2 tahun berikutnya, Depresi Pasca stroke terjadi seperempat pasien stroke dalam waktu 4 bulan stroke. Lebih dari separuh pasien mengalanti depresi Perjalanan penyakit stroke beragam, ada pasien yang pulih sempurna ada pula yang sembuh dengan cacat seumur hidup. Yang paling banyak cacat adalah pada kelompok umur di atas 45 tahun.
9. Analisis Faktor jenis Stroke dengan terjadinya depresi di poliklinik syaraf RSUD Ulin Banjarmasin

Jenis stroke Klien pasca stroke di Poliklinik Syaraf RSUD Ulin Banjarmasin semuanya adalah SNH, Klien yang mengalami depresi ringan sebanyak 30 orang $(45,5 \%)$ dan yang mengalami depresi sedang sebanyak 20 orang $(30,3)$. Hal ini sesuai dengan angka statistik stroke (2013) yang mengatakan $85 \%$ dari keseluruhan stroke adalah SNH dan $15 \%$ sisanya adalah SH.

Menurut Cojocaru (2013) depresi setelah stroke berhubungan dengan peningkatan mordibitas dan mortalitas selain itu gejala depresi bahkan bisa memburuk selama fase kronis setelah stroke. Prevalensi gejala depresi lebih tinggi pada pasien stroke dibandingkan dengan pasien lain. Depresi adalah penyakit neuropsikiatri yang paling sering terjadi pada iskemia otak, mempengaruhi hingga $35 \%$ dari semua pasien. Depresi paska iskemia otak dapat memperlambat 
pemulihan fungsional, kognisi dan sosio integrase.

\section{Analisis Faktor Dukungan Sosial dengan} terjadinya depresi di poliklinik syaraf

\section{RSUD Ulin Banjarmasin}

Menunjukkan bahwa Klien pasca stroke di Poliklinik Syaraf RSUD Ulin Banjarmasin memiliki dukungan sosial yang baik dengan tingkat depresi ringan sebanyak 20 orang $(30,3 \%)$ yang dimana ada 10 orang $(15,2 \%)$ memiliki dukungan sosial sedang dengan tingkat depresi ringan. Klien yang memiliki dukungan sosial yang sedang dengan tingkat depresi sedang sebanyak 20 orang $(30,3 \%)$ dan klien yang memiliki dukungan sosial baik tidak ada yang mengalami depresi sedang.

$$
\text { Hasil analisis dengan }
$$
menggunakan uji statistik Spearmen-Rank menunjukkan $\mathrm{p}$ value sebesar 0,000 , nilai tersebut secara statistik bermakna $p(0,000)$ $<\alpha(0,05)$ maka Ho ditolak.

Penelitian ini sejalan dengan penelitian Rahman (2017) hasil uji Spearman Rank didapatkan hubungan yang signifikan antara dukungan informasi keluarga terhadap tingkat depresi pasien paska stroke $(p=0,000)$, dan terdapat hubungan yang signifikan antara dukungan penghargaan keluarga dengan tingkat depresi pasien paska stroke $(p=0,000)$. Nilai hubungan dukungan informasi keluarga adalah positif, yang berarti semakin meningkat nilai dukungan informasi dari keluarga sebanyak 1 kali maka akan meningkatkan kualitas hidup penderita stroke pada fase pasca akut sebanyak $40 \%$. Sistem dukungan sosial pada keluarga akan memengaruhi perilaku hidup sehat. Anggota keluarga berperan penting dalam memberikan informasi pencegahan penyakit dan promosi kesehatan serta pemulihan akibat gangguan kesehatan. Sumber dukungan informasi adalah keluarga, yang berfungsi sebagai sebuah kolektor dan penyebar informasi.

\section{Analisis Faktor Tipe Keperibadian} dengan terjadinya depresi di poliklinik syaraf RSUD Ulin Banjarmasin

Menunjukkan bahwa Klien pasca stroke di Poliklinik Syaraf RSUD Ulin 
Banjarmasin sebagian besar memiliki Tipe

Kepribadian ekstrovert yang mengalami depresi ringan sebanyak 26 orang $(39,4 \%)$

klien dengan Tipe Kepribadian Introvert hanya ada 4 orang yang mengalami depresi ringan $(6,1 \%)$. Klien yang memiliki tipe kepribadian ekstrovert yang mengalami depresi sedang ada 17 orang $(25,8 \%)$ dan klien yang memiliki tipe kepribadian introvert yang mengalami depresi sedang ada 3 orang $(4,5 \%)$.

Hasil analisis dengan menggunakan uji statistik Spearmen-Rank menunjukkan $\mathrm{p}$ value sebesar 0,827 , nilai tersebut secara statistik bermakna $p(0,827)>\alpha(0,05)$ maka Ho diterima.

Hal ini bertolak belakang dengan penelitian Silaen dkk (2008) dimana terdapat hubungan antara perubahan kepribadian dengan total HAD skor pasien. (Pearson correlation coefficient $=0,576 ; p$ $=0,0001)$. Dijumpai hubungan yang bermakna antar perubahan kepribadian dengan gangguan emosional (HAD skor) pada penderita. Salah satu komplikasi stroke yang penting dan sering terlewatkan adalah depresi. Ciri kepribadian yang baru dapat timbul ataupun kepribadian yang lama menjadi menonjol. Insiden kumulatif depresi (gangguan emosional) satu tahun sekitar $38,7 \%$ pada pasien pasca stroke dan kepribadian neuroticsm merupakan faktor yang potensial rentan untuk terjadinya depresi pasca stroke.

Sedangkan menurut Suwantara (2004) Serangan stroke dapat merubah sikap dan kognitif penderita. Gangguan kognitif pasca-stroke dapat mengenai pikiran (thinking) dan ingatan (memory) yang mengakibatkan lebar perhatian (attentionspan) menyempit. Pada gangguan ini juga dijumpai adanya defek di dalam ingatan jangka pendek dan hilangnya kemampuan untuk mengikuti instruksi, bahkan pada sebagian penderita juga terdapat gangguan anosognosia.

\section{Daftar Pustaka}

Azzoni, G. Gainotti. A. And C. Marra. (2017). Frequency, phenomenology and anatomical-clinical correlates of major post-stroke depression. The British Journal of Psychiatry. Access on June 1, http://bjp.rcpsych.org/

Audina, Dhea. (2016). Usia, Jenis Kelamin Dan Klasifikasi Hipertensi Dengan 
Jenis Stroke Di RSUD dr. Zainoel Abidin Banda Aceh. Skripsi. Program Studi Ilmu Keperawatan Fakultas Keperawatan Universitas Syiah Kuala Banda Aceh

Astrom M, Adolfsson R, Asplund K. Major depression in stroke patients: a 3-year longitudinal study.

Stroke. 1993;24:976-982. doi: 10.1161/01.STR.24.7.976

Asmawati, Rusmini, Nursardjan .(2009) Hubungan Usia dan lamanya Menderita Stroke Dengan Kejadian Depresi Pasca Stroke Di Poli Saraf Rsij Mataram. Jurnal Kesehatan Prima Vol. 3. No. I Februar1: 414 - 427

Amanda G Thrift, Tharshanah Thayabaranathan, George Howard, Virginia J Howard, Peter M Rothwell, Valery L Feigin, Bo Norrving, Geoffrey A Donnan, and Dominique A Cadilhac. 2016. Global Stroke Statistics. International Journal Stroke $0 \quad$ (0) 1-20: $\quad$ DOI: $10.1177 / 1747493016676285$

wso.sagepub.com Available from: https://www.researchgate.net/publicat ion/309543155_Global_stroke_statisti cs [accessed Sep 13 2018].

Basit, Muhammad., Dini Rahmayani. (2017). Quality of Life of Post-Stroke Patients at the Nerve Clinic of Ulin General Hospital. https://www.atlantispress.com/proceedings/smichs$17 / 25889718$

Burhanuddin, M., Wahiduddin dan Jumriani, 2012. Faktor risiko kejadian stroke pada dewasa awal (18-40 tahun) di Kota Makasar Tahun 2010-2012. http://repository.unhas.ac.id/(sitasi 17 November 2014).

Benny M. Silaen, Aldy S. Rambe, dan Darulkutni Nasutio. 2008. Hubungan antara Perubahan Kepribadian Pasca-stroke dengan Ansietas dan

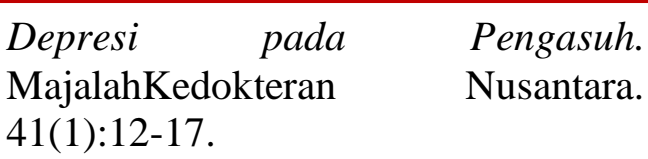

Berkel, H. (2009). The Relationship BetweenPersonality, Coping Styles and. Stress, Anxiety and Depression. (Thesis). University of Canterbury.

Dinas Kesehatan Provinsi.Profil Kesehatan Kalimantan Selatan Tahun (2008). Banjarmasin: Dinas Kesehatan Provinsi Kalsel

Darussalam, M. Analisis Faktor-Faktor yang Berhubungan dengan Depresi dan Hopelessness pada Pasien Stroke Di Blitar. Jakarta : Indonesia. Universitas Indonesia; 2011.

Eun-Young Park, Jung-Hee Kim (2017). An analysis of epressive symptoms in stroke survivors: verification of a moderating effect of demographic characteristics.BMC

Psychiatry.doi: 10.1186/s12888-0171292-4

Hawari, D. (2002) Manajemen Stres, Cemas dan Depresi, Jakarta : Balai Penerbit FKUI

Nastiti, Dian.(2012). Gambaran Faktor Resiko Kejadian Stroke Pada Pasien Stroke Rawat Inap Di RS. Karakatau Medika Tahun 2011. Skripsi: Fakultas Kesehatan Masyarakat Universitas Indonesia

Robinson, Robert G., M.D., Ricardo E. Jorge, M.D. (2016). Post-Stroke Depression: A Review. Department of Psychiatry, Carver College of Medicine, University of Lowa, Lowa City. 